\title{
Post-harvest management and associated food losses and by-products of cassava in southern Ethiopia
}

- Aditya Parmar

- Asnake Fikre

- Barbara Sturm

- Oliver Hensel

\begin{abstract}
Improved (high yield and disease resistant) cassava varieties were introduced into Ethiopia around the onset of the twenty-first century, as a potential food security crop. At present, limited information is available from the country on post-production aspects of the value chain (VC) and related food losses. The lack of such data prevents policymakers and VC actors from taking steps towards improving VC efficiencies, which can have a significant impact on livelihoods and food security. The focus of this study was to examine the prevailing post-harvest practices in the cassava VC in southern Ethiopia and quantify the extent of food losses and associated by-products in the framework of the recently developed 'food loss and waste protocol'. The majority of the cassava in the study area was processed into dry chips and milled into a composite flour with teff and maize to prepare the staple bread (injera). 'Critical loss points' were during sun-drying (4\%) and stockpiling at farm and marketplace (30-50\%). Insect pest damage was primarily responsible for food losses at farm and market level. The most important insect species infesting dry cassava were identified during the survey. As far as the by-products were concerned, the ratio of leaf:wood (stem and stump):starchy root on a dry matter basis at harvest was 1:6:10. Further emphasis should be on improving processing and storage technologies to reduce food losses and the better recovery and utilisation of by-products, especially the leaves of cassava, which could be a potential source of protein in human diets.
\end{abstract}

\section{Keywords}

Cassava Ethiopia Food losses Inedible parts Value chain Insect-pests

\section{Introduction}

The southern region of Ethiopia is known for its high population density (with several districts having densities of 300-500 people $/ \mathrm{km}^{2}$ (Adugna 2014)) and production of space and time effective root and tuber crops (Lebot 2009), such as enset (Enset ventricusum), potatoes (Solanum tuberosum), sweet potatoes (Ipomoea batatas), taro (Colocasia esculenta), and cassava (Manihot esculenta). For example, in Africa, cassava provides

$50,000 \mathrm{kcal} / \mathrm{ha} / \mathrm{day}$, in comparison to about 20,000 to 25,000 for wheat, rice and maize (based on FAOSTAT 2016; USDA 2016). Cassava has been produced and consumed at smallholder level as a food security crop in southern Ethiopia for several decades (Taye and Biratu 1999; Mulualem and Weldemicheal 2013; Haile 2015). The importance of cassava as a water-stress 
resistant crop has increased in the country since the drought-induced famine of 1984-85 when approximately one million Ethiopians lost their lives and 2.5 million were displaced internally (Nebiyu 2006; Yebo and Dange 2015). National research programs and the government of Ethiopia have considered cassava as a potential crop to address general food insecurity due to recurring droughts and erratic rainfall in the country (EARO 2000; Nebiyu 2004; Anshebo et al. 2004; Kassa 2013). The improved cultivars (high yielding and cassava mosaic disease (CMD) resistant) were introduced by the International Institute of Tropical Agriculture (IITA) in the country with the collaboration of the national research programs in 2005-2007 (Anshebo et al. 2004; Atser 2012; Mulualem 2012). At present, the majority of cassava is produced and consumed in the southern, southwestern and western parts of the country (Taye and Biratu 1999; Anshebo et al. 2004; Mulualem 2012; Haile 2015). Overall, there is a lack of reliable data from the country on cassava production and consumption. However, the southern regional agricultural bureau estimates that cassava production has increased fivefold since the introduction of improved cultivars and the expansion of area under cultivation. In the years 2000 to 2004 approximately 50,000-60,000 tons of cassava was produced on $\sim 5000$ ha, in comparison to 250,000 tons on 12,800 ha (average yield of $\sim 19.53$ tons/ha) in 2011 (Tadesse et al. 2013; Haile 2015). Preliminary reports from the southern region of the country suggest that cassava is consumed more frequently in lowincome households, and fills the food shortage periods of the year, when supplies of cereal crops such as maize and teff are short (Haile 2014; Balta et al. 2015; Legesse and Geta 2015). Webb et al. (1992) mentioned that during a household survey in the Wolayita zone, in 1985, $50 \%$ of the respondents claimed that cassava as a source of food and income was crucial to replacing some of the losses of other crops. In a relatively recent study, Legesse (2013) concluded that in one of the districts (Amaro), in the southern region, the households that were involved in cassava production were better off regarding calorie intake and income than the households which did not cultivate cassava. Abuye et al. (1998) associated high consumption of cassava in three villages of the Gamo-Gofa zone (in southern Ethiopia) with the increased prevalence of goiter; however, in the recent literature (Haile 2015), there has not been a report of cassava toxicity (perhaps due to the introduction of improved varieties).

The majority of the research and development on cassava in Ethiopia has focused on crop production, particularly cultivar adaptability and selection (Nebiyu 2004, 2006; Mulualem 2012; Mulualem et al. 2012; Shonga et al. 2012; Mulualem and Weldemicheal 2013; Laekemariam 2016), and nutritional and anti-nutritional factors (Desse and Taye 2001; Enidiok et al. 2008; Nebiyu and Getachew 2011; Kebede et al. 2012; Haile et al. 2014; Haile 2014). The research on post-harvest food losses of cassava in the country is deficient; literature available on cassava from the country is not adequate to conduct a comprehensive post-harvest food loss assessment (Tadesse et al. 2013; Yebo and Dange 2015; Mulualem and Dagne 2015; Markos et al. 2016). The lack of such information prevents the national research institutes, government, development organisations and other stakeholders from recognising the socioeconomic, nutritional and environmental significance of the problem (FLWP 2016). Global annual estimates of cassava food losses are close to 30-40\% (Westerberg et al. 2012; Naziri et al. 2014). Such significant losses can have a direct impact on food security and income of smallholders and the poor in developing countries like Ethiopia, with large populations (105 million (UN 2017)), and high prevalence of undernourishment (32\% of the population (GFSI 2014)).

The objective of this study was to assess the current state of the cassava post-harvest value chain (VC) from harvest to retail in the southern region of Ethiopia; to illustrate the key actors and their roles; and, assess the magnitude and related causes of the food losses and 
other by-products associated with production and processing. The particular focus was to assess how much, where and when cassava food losses occur and what are the main contributors to these losses. Past experience shows (Gustavsson et al. 2011; Hodges et al. 2011; Kummu et al. 2012) that the food losses at consumption stage (sometimes referred as 'food waste') is a phenomenon of the developed world (rich economies, where food is in abundance), hence the consumption stage of the $\mathrm{VC}$ was not considered for this assessment.

\section{Material and methods}

\subsection{Study sites}

In consultation with the Ethiopian Institute of Agricultural Research (EIAR) and the regional agricultural research stations, three woreda (sub-regional administrative divisions): Sodozuria, Ofa, and Kindo-koysha in the Wolayita zone of the SNNPR (Southern Nations and Nationality People's Region) were identified for the study. In each woreda, three kebele (smallest administrative division) were selected, covering a total of nine kebele namely: Wachiga-Busha, Tome-gerere, Bukama-fekaka, Dakaya, Wachiga-yesho, Sere-yesho, Molticho, Hanaze, and Zebeto. Apart from the woreda level town markets (Sodo, Gesuba and Bale), three major urban markets namely Hawassa, Arba-minch, and Shashemene surrounding the zone were also surveyed (Fig. 1).

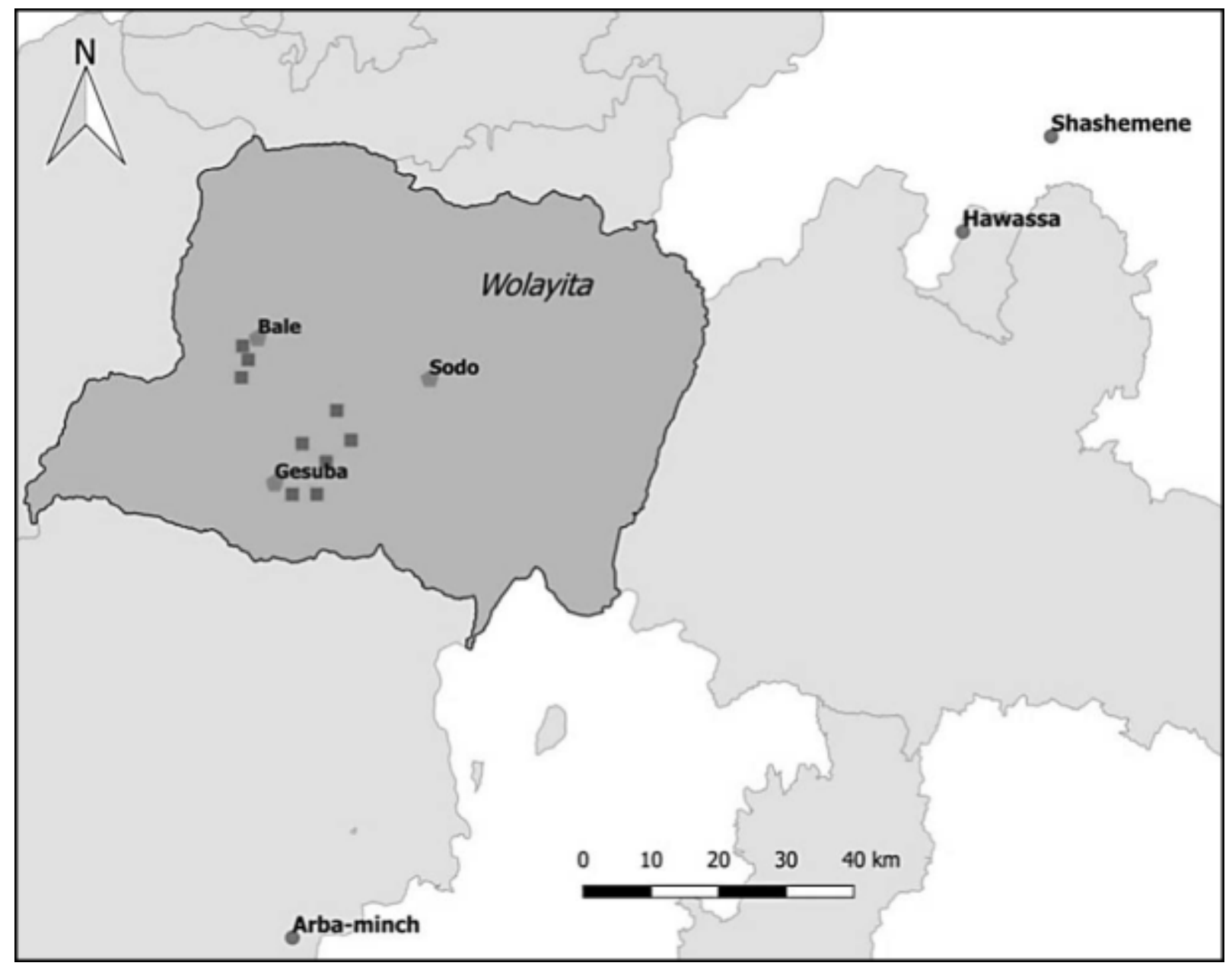

Fig. 1 
Map of the study area. (Square dots represent the coordinate locations of individual kebeles). (Source: Generated by QGIS 2.8.1 mapping tool by the first author, using the coordinates collected by Garmin GPS device)

The Wolayita zone is located at $6^{\circ} 36^{\prime}$ to $7^{\circ} 18^{\prime}$ north latitude and $37^{\circ} 12^{\prime}$ to $38^{\circ} 24^{\prime}$ east longitude and at an altitude ranging from 700 to 2940 m.a.s.l. The vegetation is classified as wood bushland, and topography consists of rocky, undulating plateaus, mountains and steep slopes with the highest peak of an extinct volcano (Mount Damota) extending into Lake Abaya and Omo river (Bekele and Butako 2011). The soil classification varies from Humic Nitosols and Chromic Luvisols in Sodo-zuria to Lithic Leptosols in Ofa and Kindo-koysha. The rainfall pattern is bimodal: June - October as long rainy season and March - April as the short rainy season. Annual precipitation ranges from 1000 to $1800 \mathrm{~mm}$ in the zone (NMSA 1996).

The Wolayita zone is one of the most populated parts of the region with a population density of over $351 / \mathrm{km}^{2}$. About $90 \%$ of the zonal inhabitants reside in the rural area having agriculture and livestock rearing as their primary economic activities (CSA 2007). The rural communities of the zone often face a moderate food consumption gap (USAID 2016). Balta et al. (2015) reported that up to $72 \%$ of the households in Sodo-zuria woreda experience food shortages for up to six months in a year, and rely on food aid. Some of the key limiting factors leading to such a situation in the area are erratic rainfalls, soil infertility, soil erosion and the increasing population density. The principal crops in the study area are maize, ensete, cassava, sweetpotato, red-beans (haricot beans), taro, yams, teff, and coffee.

\subsection{Conceptual framework: Food loss quantification}

'Food loss and waste accounting and reporting standard' (FLWP 2016) was the guiding approach for the study. The methodology is a recent development towards standardising food loss and waste assessments and is the result of a multi-organization collaboration among which the Food and Agriculture Organisation of the United Nations (FAO), the United Nations Environment Programme (UNEP) and the World Resource Institute (WRI) were some of the leading contributors. The purpose of a global quantification standard is to maintain consistency in measurements and to enable efficient tracking of food losses and wastes.

The definitional and structural framework based on FLWP (2016) in the context of the current study is described in Fig. 2 . The four essential components of the methodology are the material types (food and inedible parts), destinations, time frames, and boundaries. The combination of these four dimensions is defined as the scope of the study. 
Open image in new window

Material Type:

Food -The part of the biomass produced intended for human consumption.

Inedible parts - Component associated with food production which is not intended for human consumption.

Food loss - Part of the 'food' which is not consumed.

\section{Destination:}

The final destination of the 'food loss' and 'inedible parts'

produced along the value chain.
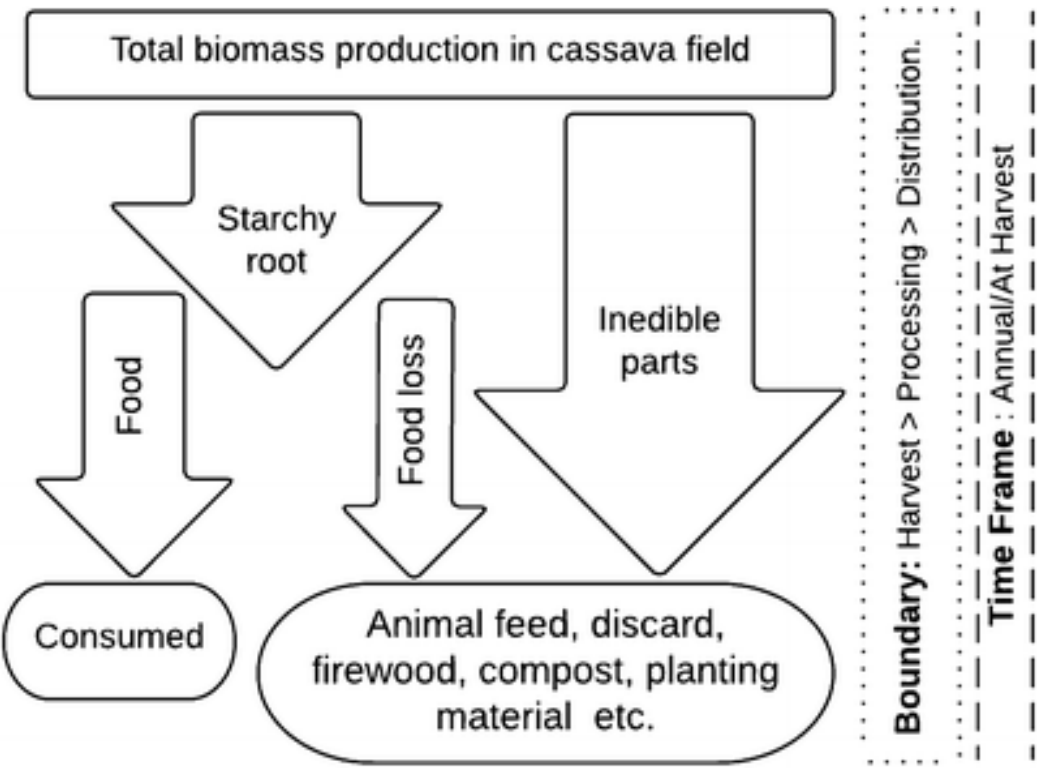

Fig. 2

Conceptual frame and scope of the assessment. (Source: Based on FLWP,2016)

The majority of the dehydrated cassava chips were traded $(\sim 95 \%)$ and were later milled into flour to serve as a supplementary to teff (Eragrostis tef) and maize (Zea mays) in a composite flour for the preparation of injera (Ethiopian staple flatbread). The material types which were considered for quantification were food loss and inedible parts (or by-products) along the VC with their specific destinations. Boundaries were set from harvest to retail for the dried cassava VC (which included processing of fresh roots into cassava chips and flour). The flow of the major VC steps (production, harvest and post-harvest activities) and associated actors considered for the study are presented in Fig. $\underline{3}$. The VC map also presents the tools and facilities used by the local producers, labor requirements and gender segregation of the activities. 
Open image in new window

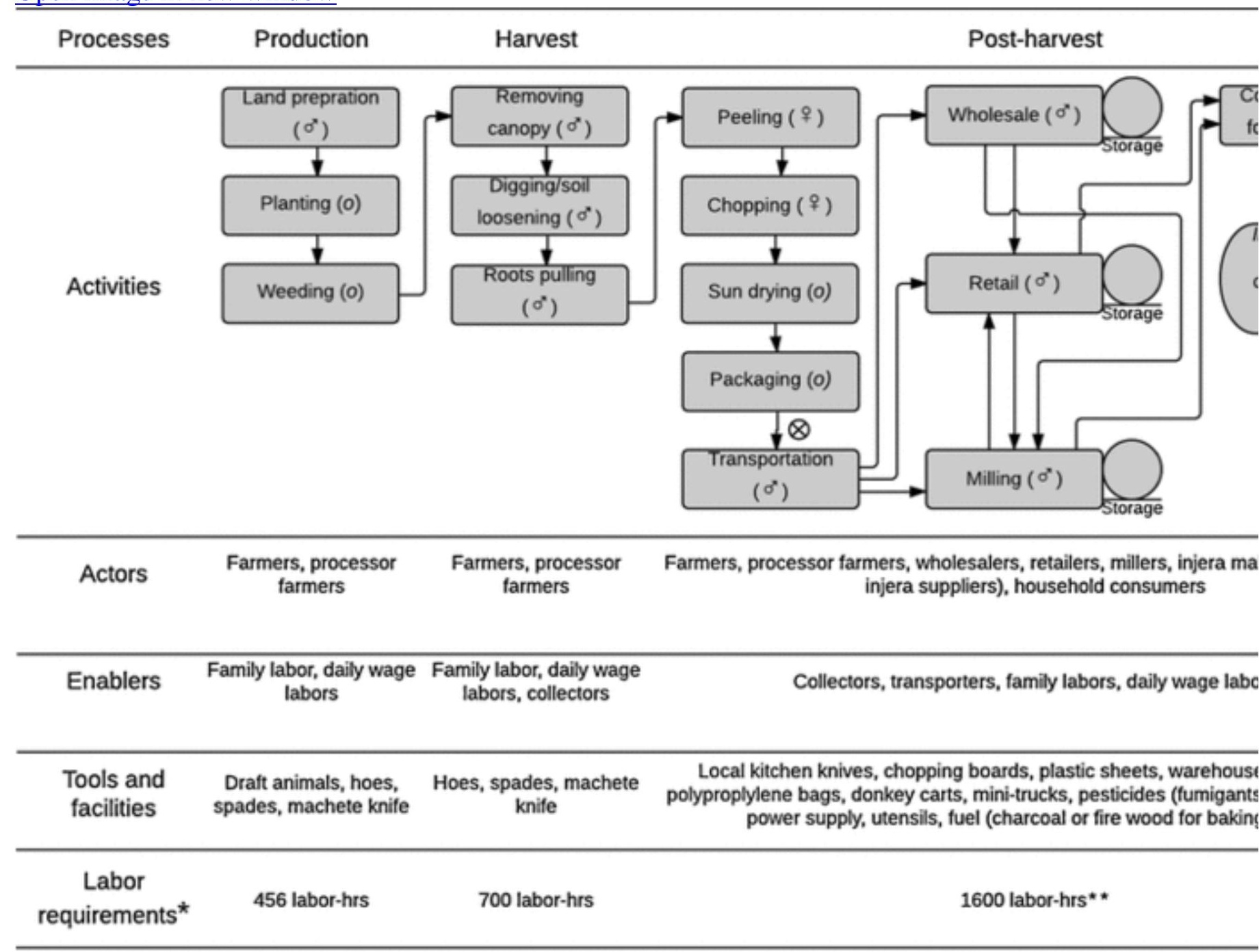

(o) Gender neutral activities: performed by men and women; $\left(\sigma^{x}\right)$ Male dominated activities; ( + ) Female dominated activities: (approximate assessment for a yield of 20 tons/ha). **Only peeling and chopping activities.

Fig. 3

Value chain map of dried cassava in the Wolayita Zone, Ethiopia

\subsection{Data collection and analysis}

The FLW standard provides a diverse range of quantification tools depending on the framework of the study and available resources. During this study, the "measurements and approximations' tools were used, which include 'direct weighing', 'assessing volumes' and 'survey' along the post-harvest VC (harvest to retail) of dry cassava. The study was carried out during the Meher harvest season (October to February) 2015/16. A cross-sectional survey in addition to direct weighing is critical for designing effective intervention strategies, as it provides insights into attitudes, values, and limitations associated with particular food losses (FLWP 2016). A total of $137 \mathrm{VC}$ actors were interviewed which included 74 traders (wholesalers, millers, and retailers), and 63 farmers. Background characteristics of the respondents with their locations are presented in Table 1 . Open and closed questionnaires were administered in the study area to collect quantitative and qualitative data on production 
and post-production management of crop, food loss and inedible parts during harvest, processing, and marketing of dry cassava.

Table 1

Background characteristics of value chain actors

Background characteristics

Location

(Towns/Woreda)

Sodo (Sodo-Zuria)

Bale (Kindo-koysha)

Gesuba (Ofa)

Arba-minch

Hawassa

Shashemene

Sex

Male

Female

Age (years)

$\begin{array}{ll}\leq 30 & 34.4 \\ 31-40 & 31.3 \\ 41-50 & 21.9 \\ \geq 51 & 12.5\end{array}$

Education

No education

$$
0.0
$$

16.1

61.3

Junior secondary

12.9

University/College

9.7

Household size (persons)

$$
\begin{array}{ll}
\leq 5 & 51.9 \\
5-10 & 40.7 \\
>10 & 7.4
\end{array}
$$

Landholding (hectare)

$$
\begin{array}{ll}
\leq 1 & \text { NA } \\
>1 & \text { NA }
\end{array}
$$

\section{VC actors (Percentages \%)}

$$
\begin{gathered}
\text { Wholesalers } \\
(n=32)
\end{gathered}
$$

$\begin{array}{cc}\text { Retailers } & \text { Millers } \\ (\mathrm{n}=19) & (\mathrm{n}=\mathbf{2 3})\end{array}$

Farmers/ processors

$\begin{array}{lll}36.8 & 52.2 & 41.3\end{array}$

$\begin{array}{lll}36.8 & 26.2 & 19.0\end{array}$

5.3

13.0

39.7

10.5

0.0

NA

0.0

4.3

NA

10.5

4.3

NA

farmers $(n=63)$ $\begin{array}{lll}84.2 & 100.0 & 69.8\end{array}$

$\begin{array}{llll}.4 & 15.8 & 0.0 & 30.2\end{array}$

3.4

31.6

$30.4 \quad 36.6$

42.1

22.2

15.8

25.2

10.5

21.7

16.0

4.3

8.7

25.4

0.0

30.4

33.3

10.5

52.2

38.1

21.1

0.0

15.8

4.3

3.2

$4.3 \quad 3.2$

The specimens of insects infesting dry cassava were collected randomly from 3 to 4 infested cassava chips sacks during visual observation (by hand and vial as described in Grootaert et al. (2010)) from 24 wholesalers' storage warehouses (11, 11 and 2 in Sodo, Gesuba and Bale, respectively) for taxonomic identification. The insect specimens were kept in $70 \%$ ethanol until identified. 
Data collected from the survey and measurements were initially inserted in Microsoft Excel 2016 (Microsoft Corporation, USA), and subsequently scanned, coded and analysed using the Statistical Package for Social Science (SPSS) 22 (IBM, Armonk, NY, USA), and SigmaPlot 12 (Systat Software Inc., California, USA) a scientific graphing and statistical analysis software. The principal statistical analyses employed were univariate (frequency distribution, central tendencies and dispersion), bivariate (t-test $(P \leq 0.05)$ and cross tabulations.

\section{Result and discussion}

\subsection{Value chain characteristics}

Smallholder farms cultivated the majority of the cassava in the Wolayita zone with laborintensive agronomic methods (refer to Table 1 and Fig. $\underline{3}$ ). The prominent cassava VC actors in the study area were farmers (who plant and sell standing crops to collectors or other processor farmers); processor farmers (who plant, procure standing crops and process fresh cassava into dried chips), wholesalers, retailers, and millers (refer to Fig. 3 ). Some of the enabling actors who are essential for production and marketing of dry cassava include casual laborers (including family labor), and collectors (brokers, who were an intermediary between processor farmers and wholesalers). Due to the labor intensive nature of cassava harvesting and processing, about $13 \%$ of the total farmers surveyed were selling their standing crop to the processor farmers (remaining 87\%). Sixteen percent of the respondent processor farmers were selling the dried product to collectors to avoid the inconvenience of arranging transportation and labor for loading and offloading. However, the majority $(\sim 80 \%)$ sold their products (sun-dried chips and chunks) directly to wholesalers and retailers in woreda level markets.

At rural household level, fresh cassava, like other roots crops such as sweetpotato and taro, were boiled with red beans and served with local sauces as a staple food. However, as previously mentioned, the majority of cassava was subjected to drying and milling into flour to make a composite with teff and maize for the production of the final product, injera. As the industrial application of cassava in Ethiopia is still in the development phase only a small part of the production was used to produce industrial starch and adhesive. Dried cassava was transported up to $400 \mathrm{~km}$ to the national capital industrial area. Collectors from Sodo reported about 1000 tons of cassava were transported monthly to Addis Ababa, one-third of this quantity was used in the non-food industry whereas the majority went into the food supply chain of the national capital and adjoining areas.

\subsubsection{Production}

About $33 \%$ of the surveyed cassava farms in Wolayita zone were larger than half a hectare, and $63 \%$ of the farms were mono-crop plantations. Qulle (104/72 Nigeria red) and Kelle (44/72 Nigerian white) were the commonly-grown, improved cassava varieties in the study area (high yield, disease resistant and low toxicity) introduced into the country from Nigeria (Anshebo et al. 2004; Atser 2012). Farmer to farmer exchange and self-multiplication was the primary source of planting material. Only $12.7 \%$ of the respondents mentioned government and non-government bodies as an initial source of planting material. The yields in the Wolayita zone for the Qulle cultivar was approximately 20 t/ha from a 24 monthold plantation (based on direct weighing and measurement data from three locations and discussions with crop holders). The average yields on researcher managed sites for the 
varieties (Qulle and Kelle) reported from the southwestern part (Jimma zone) of Ethiopia ranged from 36 to 49 t/ha (Mulualem and Weldemicheal 2013). Various other studies from the region also reported similar yields (on the farm) ranging from $23 \mathrm{t} / \mathrm{ha}$ in the Jimma zone (Mulualem 2012) to 20-24 t/ha in the southern region (Tadesse et al. 2013; Mulualem and Dagne 2015; Markos et al. 2016). The most important criteria for farmers to select a cultivar were high yield and availability of low-cost planting material; these findings are similar to previous studies which reported yield, drought tolerance and early maturing as some of the important cassava cultivar selection criteria for farmers in the region (Mulualem and Dagne 2015). Previous reports on the toxicity (cyano-glycoside content) of Qulle and Kelle cultivars from Ethiopia showed a cyanide content of 69 and $50 \mathrm{mg} / \mathrm{kg}$ in fresh peeled root, respectively, which may be reduced to below detection levels after processing into flour and the final preparation of fermented flatbread injera (Nebiyu and Getachew 2011; Kebede et al. 2012). No incident of acute or chronic cyanide toxicity due to cassava consumption was reported from the study area during the survey.

Inter-cropping was practised by nearly one-third of the farmers, mostly with common beans during the first six months to a year from planting cassava before the canopy developed. In a recent review of the development of cassava agronomy for the last two decades in Ethiopia, Markos et al. (2016), highlighted that intercropping with haricot beans resulted in a land equivalent ratio of 1.82, which was the highest among all the other (cowpea, soybean, mung bean) intercrops.

The most valuable inputs for cassava cultivation in the study location were labor and land; the majority of farms were rain-fed and had no applications of mineral fertilisers. Out of nine major cassava producing kebele in the zone, only one (kebele Dakaya in Ofa woreda) had irrigation facilities. More than $90 \%$ of the farmers did not have access to synthetic fertilisers due to cost and availability issues. Only $23.7 \%$ of the farmers had enough organic matter (farmyard manure) for cassava cultivation. These observations are in line with the results presented by Laekemariam (2016) in a study from the Wolayita zone, which reports the lack of mineral fertiliser utilisation in the region.

Tillage was performed by draft animals and manual laborers. The most common planting method was flat tilled, which is the least labor intensive when compared to forming ridges or mounds. The plant density varied from 9000 to 10,000 plants per hectare, following a typically recommended row spacing of $1 \mathrm{~m}$ (Markos et al. 2016).

Farmers did not report incidents of any major cassava disease (such as cassava mosaic virus, brown streak virus or bacterial blight) during production. However, $10 \%$ of the surveyed farms were infested by scale insects. The scale insect infestation significantly affected the leaves and stems which also have economic value in the form of animal feed and planting material (Shonga et al. 2012). The single most important species of scale insects reported from the southern region of Ethiopia was Aonidomytilus albus (Shonga et al. 2012; Tadesse et al. 2013). Other than infestation by scale insects, a few incidents of the meadow spittlebug (Family: Aphrophoridae) were detected during the survey. The nymphs of the spittlebug were found to be feeding on tender stems covered with a typical frothy material (looking like human spittle) which protects young insects from insecticides and predators. There was no evidence of significant crop losses due to these two insects; farmers in the study area were not using any particular control measure. 


\subsubsection{Harvesting}

Cassava harvesting was labor intensive with simple tools. To harvest a ton of fresh cassava roots about 35 labor-hours were required which is equivalent to $\sim$ six worker-days $(6 \mathrm{~h} /$ day based on personal observations during the survey). The labor requirement may depend on the cultivar, soil type and to some extent the harvesting season. Previous studies from Asia and Africa mention a labor requirement of up to 12 worker-days to manually-harvest one ton of cassava (Cock 1985). The planting and harvesting times aligned with local climate conditions in the study area are presented in Fig. 4.

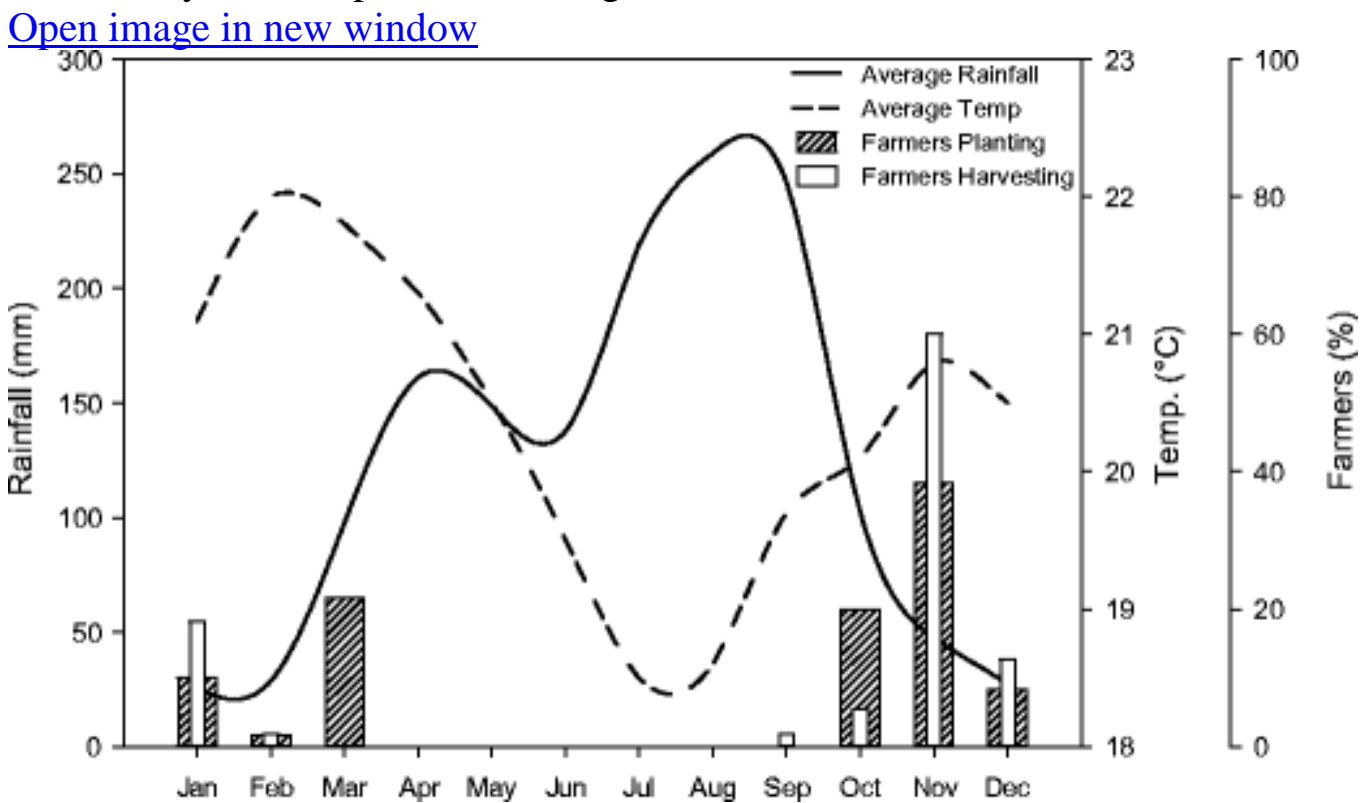

Fig. 4

Planting and harvesting frequencies in line with climate data. (Climate data: 10 years (20052015) average of mean monthly temperature and rainfall. Source National Meteorological Agency, Areka Station, Wolayita Zone)

The majority of the planting and harvesting activities overlapped with each other and took place in the dry season (October-March). In the farms where soils are not sandy, harvesting and tillage activities during the dry season may become tedious. The practice was very similar to other SSA countries where cassava is planted at the beginning of the rainy season and harvested in the following long dry season when the starch content of the roots is highest (Howeler et al. 2013). Markos et al. (2016), mentioned that the best time for cassava planting in the major cassava growing areas of Ethiopia would be from March to May. The survey revealed that more than $75 \%$ of the crop holders were planting cassava in the first four months of the dry season. However, about $25 \%$ were planted at the onset of the first rains in February and March. The peak harvest time for cassava was from October to January. In this period, $90 \%$ of the farmers were harvesting and drying cassava. The primary reason for harvest to take place in these months was due to the availability of higher solar radiations and minimal rains which are required for the sun-drying process.

The optimal harvesting maturity for cassava is about 18-24 months (Cock 1985; Bokanga 2000). Recommendations for the cultivars Qulle and Kelle from the local agricultural research station (Areka, Wolayita) were to harvest after 18 months (Markos et al. 2016), but the majority of the crop holders did not follow the recommended harvest index. The average 
time after planting for harvest was 27 months, ranging from 18 up to 36 months. The primary reason provided by the farmers for delayed harvest was to obtain higher yield, which may be due to the low input production systems where root growth takes a longer time to reach optimal yields. However, farmers reported that the starchy root tends to become woody and start rotting after 36 months. The harvesting pattern was gradual or progressive harvesting (depending on the processing capacity of the individual crop holders and market demand) over 5-6 months starting between October and November until March.

\subsubsection{Processing, packaging, and transportation}

Processing of freshly harvested cassava roots starts simultaneously with harvest without any delays. Contrary to conventional harvesting practices, processing (peeling and chopping) was primarily carried out by women and children (particularly young girls). The peeling and chopping operations were manual, using locally available household knives and chopping boards. Due to a lack of water, washing of the roots after peeling was not common practice. The dust and soil particles were brushed gently by hands or brooms before peeling. To peel and chop one ton of fresh cassava roots about 80 labor hours were required. The rough chopping led to wide deviations in slice thickness varying from 1 to $5 \mathrm{~cm}$, resulting in long periods during sun-drying. Moreover, during the peeling and chopping operations, women often sustained hand injuries. Only a few processor farmers (3\% of total responders) were in possession of a cassava chipper. This is a low capacity manually cranked instrument, constructed of mild steel and cast iron, and distributed by local non-government development organisations.

The drying process was $100 \%$ sun-drying, during the dry season. The typical drying surface was a black plastic sheet with a mean drying time of six days ranging from 4 days (with constant adequate sunshine) to 14 days (in case of cloudy or rainy conditions). Renting the plastic sheet from neighbours was also a common practice, with a daily rent of up to 30 ETB (1.5USD). About $70 \%$ of the processor farmers had plastic sheets, whereas $16 \%$ were renting and close to $14 \%$ were using brushed grass covers due to non-availability of plastic sheets. None of the processor farmers had access to mechanised or solar drying technology.

During the drying process, the mass of freshly peeled cassava reduced by $\sim 50 \%$, from an initial moisture content (MC) of $65 \%$ to a final MC of $12-15 \%$. The touch and feel method (by cracking and biting the dried chips) to test the dryness of the product to be packed and stored was the only technique available to producers to determine the optimum time to terminate the drying process. The method proved to be effective as the samples, which were approved by processor farmers after cracking and biting, had a final MC of below 13\%. A mass flow diagram at different stages of processing and usage is presented in Fig. $\underline{5}$. 
Open image in new window

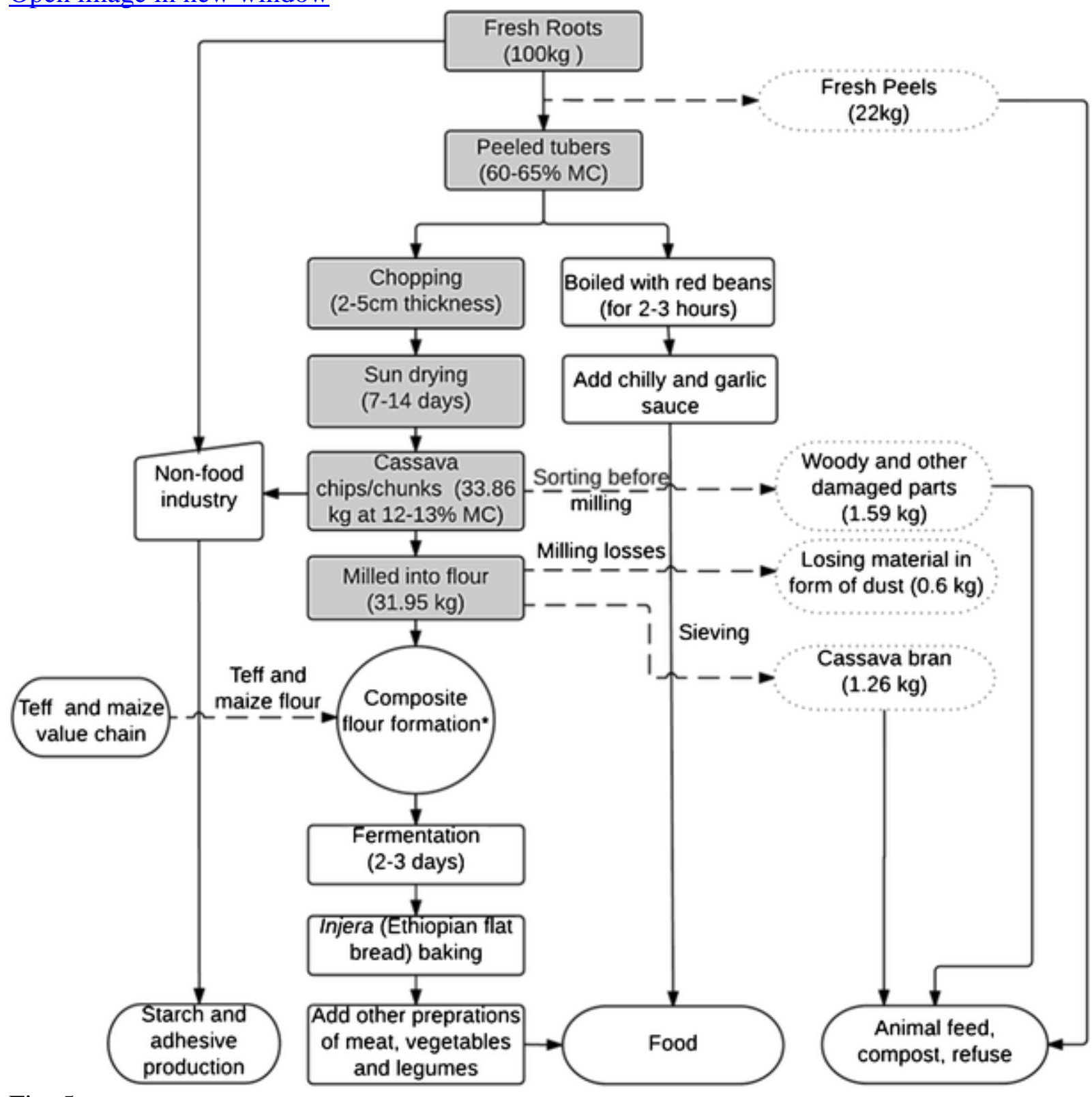

Fig. 5

Mass flow balance from fresh tubers to cassava flour. Note: *The ratio of Teff: Maize: Cassava in the study area is approximately 50:25:25. However, there are many variations, depending on the preference of consumers and price of expensive cereals such as Teff

The standard packaging for dry cassava chips or flour was $100 \mathrm{~kg}$ polypropylene sacks, which are inexpensive and easily available; such packaging was used for most of the other agricultural products nationwide. Standard transportation modes to local markets (woreda level towns) were donkey carts (capacity of 3-5 sacks), whereas, mini-trucks with a capacity of 50 sacks $(5000 \mathrm{~kg})$ were used for urban markets such as Hawassa, Sheshemene, Abraminch, and Addis Ababa. 


\subsubsection{Marketing and storage}

One of the advantages of converting fresh cassava into dried chips is that the dry product can be stored for longer periods and thus can be used to fill seasonal gaps in availability of food. Moreover, the motivation, especially for processor farmers to store dried cassava was to obtain higher financial returns. An important factor governing the price of cassava is the production season (dry season), the supply of dried cassava chips overrunning demand, causing prices to crash to their minimum. The high and low prices on average are 4.9 and 2.9 ETB $/ \mathrm{kg}$, respectively. Prices were significantly higher $(P$-value $<0.001)$ in the rainy season. Another important factor which played a role in the increased price of cassava chips and flour during the rainy season was their being the cheapest source of calories; per unit cost of cassava product was as low as $25 \%$ of teff and $66 \%$ of maize prices. Local prices of teff and maize also tend to increase during the rainy season. The seasonal variation in cassava price along with teff and maize is presented in Fig. $\underline{6}$.

Open image in new window

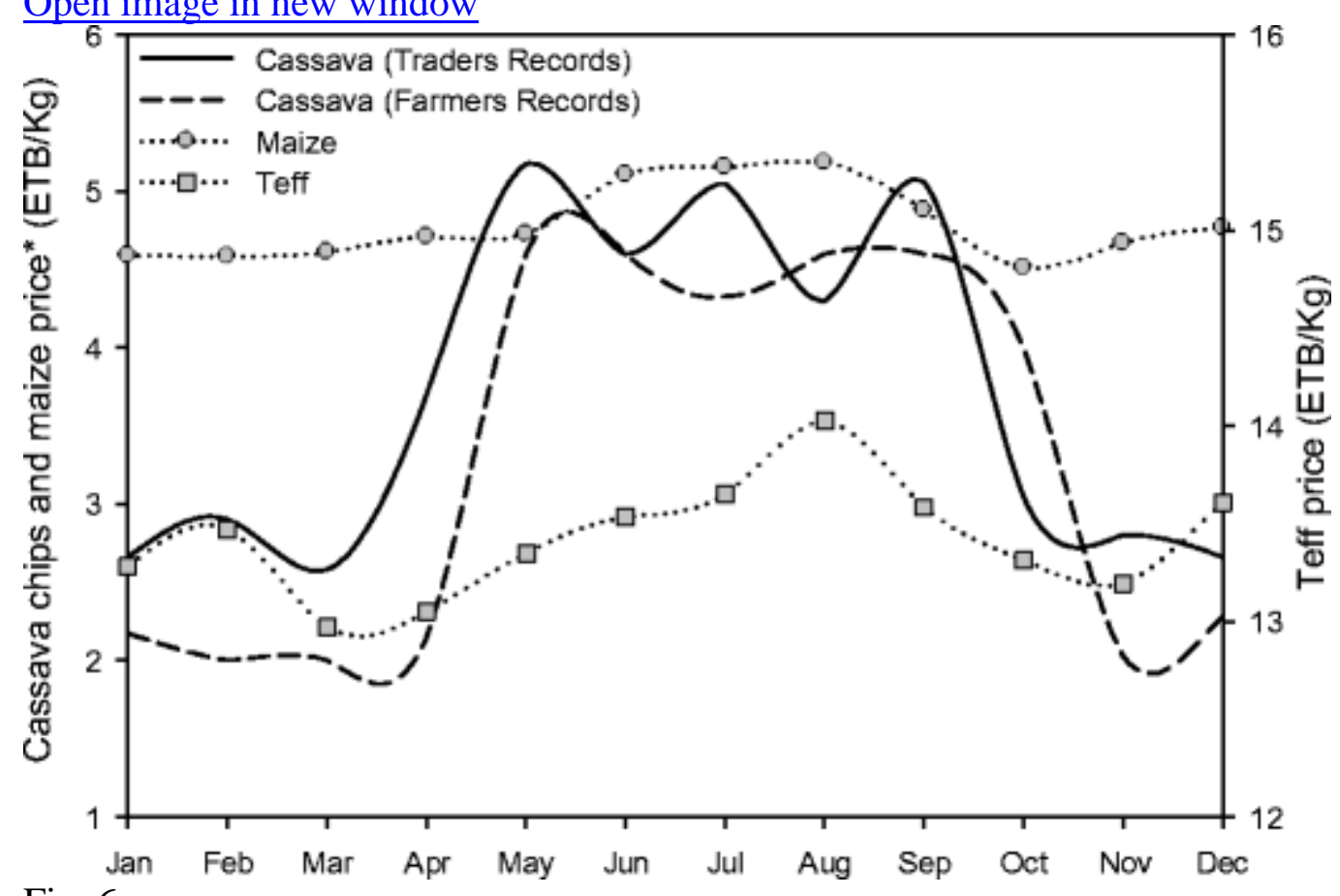

Fig. 6

Monthly price fluctuation of dried cassava chips in the study area: a comparison with primary cereals (maize and teff) which are used in a composite flour with cassava. "Note: Cassava price [Source: Survey data 2015/2016, an average of the price records from Traders (wholesalers, retailers), Farmers in the study area]. Teff (mixed) and Maize (white) price [Source: FAO, FPMA (Food Price Monitoring and Analysis Tool). Data is the average of the last three years (2014, 2015 and 2016 (up to August) wholesale price at Addis Ababa]. $\mathrm{ETB}=$ Ethiopian Birr (Exchange rate: 1USD=22.14@ Sep. 2016)

Balta et al. (2015) stated that in Sodo Zuria the peak hunger periods were from April to August, which is perfectly in line with increased cassava prices. Hence, a sudden increase in price during this time may be a result of a higher number of consumers switching to cassava use in injera or a higher proportion of cassava in the composite flour reducing the amount of the relatively costly maize and teff during the rainy season. Such a price phenomenon is prevalent in communities where a large proportion of the population is poor. Similar examples are reported from countries such as Indonesia, where an increase in the price of 
staple and more valuable crops like rice leads to higher consumption of cassava-based food products (Cock 1985).

Keeping dry products for extended periods benefits processor farmers and traders (wholesalers and retailers) economically, but storage is a challenge and a risk due to poorly managed warehouses. Consumers in the study area preferred to buy chips rather than flour and bring the chips to the mill themselves to ensure the quality of the product and prevent adulteration with pest damaged chips. Hence, most wholesalers and retailers store cassava in the form of dried chips rather than flour. Packaging and store conditions were not suited to protect the dry cassava chips from insect attack and damp. The two most pressing storage problems reported by VC actors (processor farmers and traders) were damage from insect pests and moisture related fungal growth (blackening of the cassava chips). Where some species of Aspergillus are involved, aflatoxins, which are toxic and carcinogenic, may be produced (Tadesse et al. 2013).

The four most prevalent insect pests infesting dry cassava chips in the study area were identified and ranked 1-4 with 1 as the most damaging) (Table 2). Ranks were allocated based on the damage perceived by wholesalers and retailers in three woreda markets. The most damaging pest was Heterobostrychus brunneus, the boxwood borer and auger beetle. A more detailed report on the identification and infestation of the pest from the study area has been provided by Parmar et al. (2017a). H. brunneus has been considered to be a destructive pest of dried cassava in West Africa (Stumpf 1998) and Bellotti and Schoonhoven, (Bellotti and van Schoonhoven 1978) reported H. brunneus also as a common stem borer for standing cassava crops, thus the beetle poses a dual threat. Rhyzopertha dominica, the lesser grain borer, is common in tropical and sub-tropical cassava storage systems (Golob et al. 2002), whereas Gnatocerus cornutus, the broad-horned flour beetle, is a secondary pest found in various farinaceous (starch containing) materials. Although Sitophilus zeamais is a major pest for maize, the insect is polyphagous and has been reported to infest not only cereals (buckwheat, oat, sorghum, millet) but also cassava and yam chips (Hagstrum et al. 2013). Further minor insect pests which infested dried cassava chips in the study area were Tribolium spp. and Lyctus spp., which belong to the Tenebrionidae and Bostrichidae families, respectively. One of the most damaging insects of dried cassava in SSA is Prostephanus truncatus (Hodges et al. 1985; Chijindu et al. 2008; Isah et al. 2012) but in Ethiopia it was not reported until 2015 (APHIS 2015; CABI 2015) and was not found in the surveyed area. Table 2

Major insects/pest identified infesting dry cassava in the study area

\section{Rank* Common name}

1 Box-wood borer

$2 \quad$ Lesser grain borer

3 Corn weevil

4

Broad-horned flour

\section{Species name}

Heterobostrychus brunneus Murray, 1867

Rhyzopertha dominica

Fabricius, 1792

Sitophilus zeamais

Motschulsky, 1855 beetle**

\section{Family}

Bostrichidae (Horned Powderpost Beetles)

Bostrichidae (Horned Powderpost Beetles)

Curculionidae (Snout and Bark Beetles)

Gnatocerus cornutus Fabricius, Tenebrionidae (Darkling $1798 \quad$ Beetles) 
*Note: Rank of insect species was provided by observations and discussions with traders in three woreda of the study area

**G. cornutus is a secondary pest which feeds on the powdery dust produced by an initial infestation of powder post beetles

None of the processor farmers was using any management measures for prevention of insect infestation during the storage of cassava. The majority of the wholesalers $(65 \%$ of total responders) used insecticides to manage insect infestation and re-sun-drying (opening the bags and leaving them in the sun) to prevent fungal growth. The most common insecticides which were available in the local markets and frequently used by traders as multipurpose insecticides for most crops were Malathion dust 5\% (trade name: Ethiolathion, Adamitulu Pesticides Processing Share Company, Addis Ababa) and Aluminum phosphide (56\% tablet) fumigant insecticides.

\subsection{Food losses and by-products}

One of the reasons why cassava has been so successful in low input agricultural systems of tropical and sub-tropical regions is its excellent use value. Every part of the plant is used and has economic importance (Westerberg et al. 2012). The starchy roots are used as a source of carbohydrates, the stem as planting material and firewood, the leaves as vegetable and animal feed and the peel as animal feed or compost. Hence, it is important not only to record the food losses of the cassava root but also the extent to which by-products are lost at each stage of the VC. The estimated physical quantities of food losses and associated inedible parts produced along the cassava VC with the type of material, the cause of food loss and destination use of each element are presented in Table $\underline{3}$. Storage of dry cassava chips and sun-drying process were considered to be 'critical loss points' in the cassava VC.

Table 3

Mean food losses and associated inedible parts along the dried cassava (chips/flour) value chain in southern Ethiopia

\begin{tabular}{|c|c|c|c|c|c|c|}
\hline Process & Activities & Food losses & $\begin{array}{l}\text { Inedible } \\
\text { parts }\end{array}$ & $\begin{array}{c}\text { Type of } \\
\text { material }\end{array}$ & $\begin{array}{c}\text { Destination } \\
\text { use }\end{array}$ & $\begin{array}{c}\text { Causes of } \\
\text { food losses }\end{array}$ \\
\hline \multirow{4}{*}{ Harvest* } & \multirow{2}{*}{$\begin{array}{l}\text { Removing } \\
\text { canopy }^{+}(t / h a)\end{array}$} & NEGL & $9.2 \pm 1.2$ & Stems & $\begin{array}{l}\text { Planting } \\
\text { material /fire } \\
\text { wood. }\end{array}$ & NA \\
\hline & & NEGL & $2.2 \pm 0.2$ & $\begin{array}{l}\text { Leaves } \\
\text { with } \\
\text { petioles }\end{array}$ & $\begin{array}{l}\text { Animal } \\
\text { feed/compost }\end{array}$ & NA \\
\hline & $\begin{array}{l}\text { Digging/soil } \\
\text { loosening/root } \\
\text { pulling }(\text { t/ha })^{+}\end{array}$ & NEGL & $3.8 \pm 0.9$ & Stumps & $\begin{array}{l}\text { As fire wood } \\
\text { or refuse }\end{array}$ & NA \\
\hline & $\begin{array}{l}\text { Too small and } \\
\text { woody roots } \\
(\mathrm{t} / \mathrm{ha})^{+}\end{array}$ & NA & $1.8 \pm 0.2$ & $\begin{array}{l}\text { Cassava } \\
\text { roots }\end{array}$ & Animal feed & $\begin{array}{l}\text { Too small and } \\
\text { woody for } \\
\text { processing. }\end{array}$ \\
\hline $\begin{array}{l}\text { Post- } \\
\text { harvest }\end{array}$ & $\begin{array}{l}\text { Peeling (\% of } \\
\text { unpeeled } \\
\text { roots) })^{+}\end{array}$ & $1.24 \pm 0.7$ & $21.57=$ & Peels & $\begin{array}{l}\text { Compost/ } \\
\text { animal feed }\end{array}$ & $\begin{array}{l}\text { Inappropriate } \\
\text { peeling tool }\end{array}$ \\
\hline
\end{tabular}




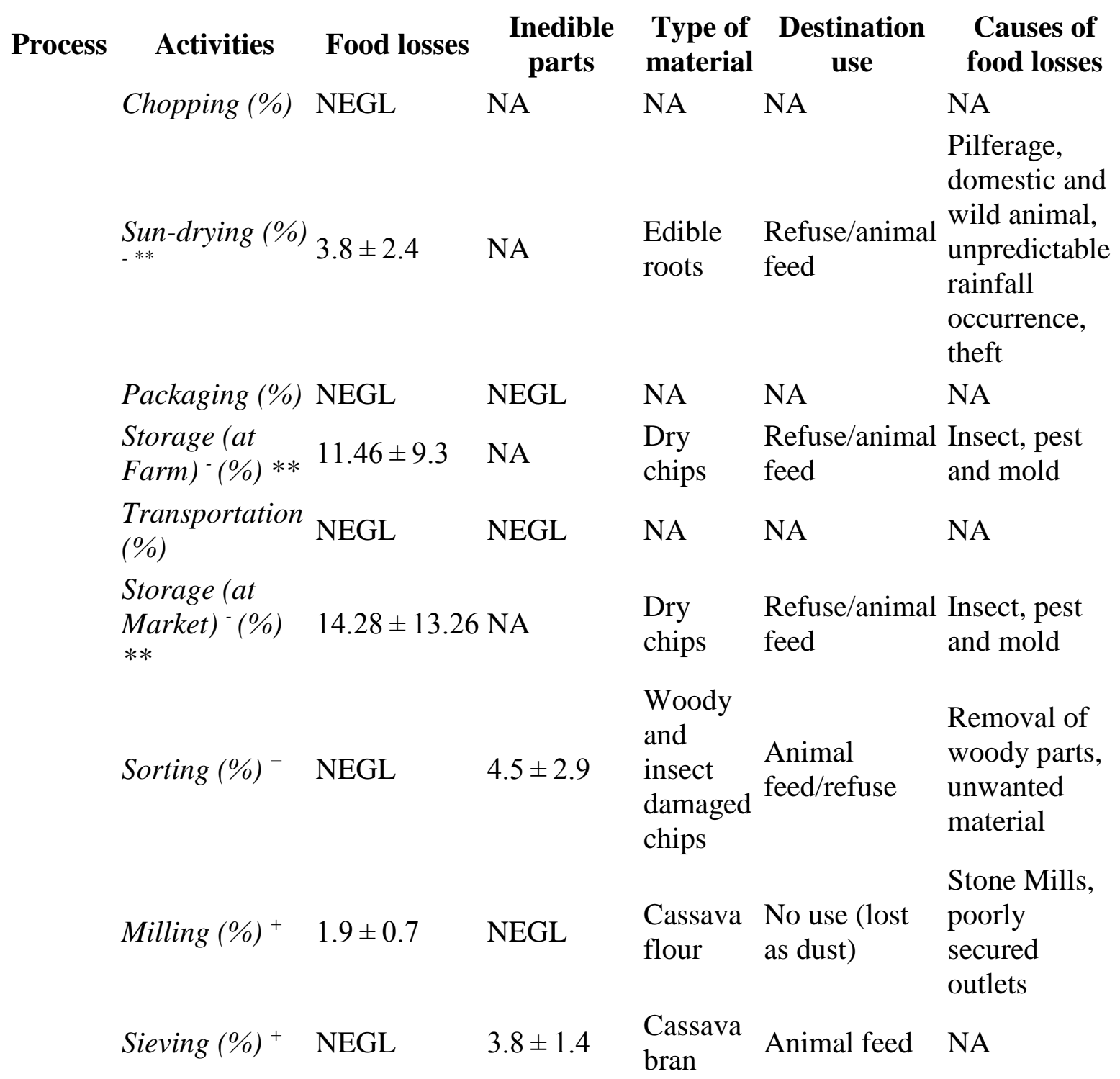

NEGL, Negligible; NA, Not applicable

*The inedible parts associated with harvest activities correspond to a yield of unpeeled tubers of $\sim 20$ t/ha of the Qulle cultivar. (+) The data is based on direct weighing (Yield data: extrapolated from plot size $8 \mathrm{~m} \times 24 \mathrm{~m}$, three replicate plots/harvest treatment). (-) The data builds on survey and questionnaire results and estimates based on experiences of VC actors at a particular stage

**Critical loss point

\subsubsection{Production and harvesting}

At harvest the relative ratio (dry matter basis) of leaf:wood (stem and stump):storage root was 1:6:10 (moisture contents of stems and leaves are $\sim 65$ and $\sim 70 \%$ respectively (Wobeto et al. 2007; Xue et al. 2015)) for the Qulle cultivar. It is hard to compare these fractions with other studies as the yields may vary significantly depending on the variety, the age of the plant, the plant density and soil fertility and climate (Ravindran 1993; Westerberg et al. 2012). Leaf dry matter reported by a previous study ranged from 1 up to 4 t/ha at root maturity Ravindran 
1993). The biomass of cassava stems can be 50\% of the root mass (Zhu et al. 2015) and this was also found in the study area where the stem biomass was close to $10 \mathrm{t} / \mathrm{ha}$ and the root yield 20 t/ha (Table $\underline{3}$ ). In the study area, cassava cultivation was primarily for its roots, whereas leaves were used as a secondary source of animal feed. Considerable portions of fresh leaves were left in the field as green manure due to practical problems of keeping the wet leaves for an extended time, fear of toxicity, cultural bias against using leaves as human food and transportation issues (personal observations of the first author). Some cassava stems were used as planting material (on farm or sold to other farmers), and the rest was used as firewood (after drying) and fencing. Food loss (the loss of edible cassava root) at production and harvesting stages was not detected.

\subsubsection{Processing, packaging, and transportation}

Mass of cassava peel varies from 15 to $25 \%$ of the whole root (Grace 1977; Oguntade 2013); it comprises an outer cork-layer (dark-brown) consisting of cork cells and phellogen and an inner part composed of phelloderm and phloem. In the study, the peel mass was about $21.6 \%$ of the unpeeled root. Due to inappropriate peeling tools and the labor-intensive nature of the work, it was hard to avoid a minor loss of pulp during peeling ( $1 \%$ of whole root mass). However, processor farmers were careful about losing starchy root mass during the peeling process. Other minor by-products during sorting of cassava chips before milling and sieving were woody and unwanted cassava parts and cassava bran (fibrous material; Table $\underline{3}$ ).

Losses during sun drying (about $4 \%$ of the fresh root mass) were mostly due to random precipitation events which resulted in fungal growth, along with other minor causes such as pilferage, consumption by wild and domestic animals and, in some extreme cases, theft. The processor farmers needed to guard the cassava during sun-drying and cover it in the event of unexpected rains. As drying takes $\sim 7$ days, at night time the product was also covered and put inside if possible to protect it from theft and wild animals.

\subsubsection{Marketing and storage}

The average food losses during storage at farm and market were the highest along the VC. A representation of variability in percentage weight loss of dry cassava (box-and-whisker plot) at the farm and market in line with frequency of storage duration (in percentage) for processor farmers and market traders is presented in Fig. 7. Approximately $30 \%$ of the processor farmers stored dried cassava chips for more than three months at the farm level, mostly due to the increased level of weight loss due to insect infestation. Conversely, $50 \%$ of the traders kept dried cassava roots in warehouses for more than three months. The storage losses indicated a linear relationship with the length of the storage period. The mean losses for more than six months storage at market warehouses was approximately $30 \%$ of the total volume stored. However, at the farm, the mean losses were close to $18 \%$ for a similar duration. At market due to the presence of various cereals and grains in the proximity of dry cassava, the swiftness and extent of infestation was higher. There was large variation in the losses for more than six months of storage; at the farm (processor farmer) the losses varied from 10 to $30 \%$, and at the market this variation was $10-50 \%$. This variation was because 'more than six months' could extend up to two years. 
Open image in new window

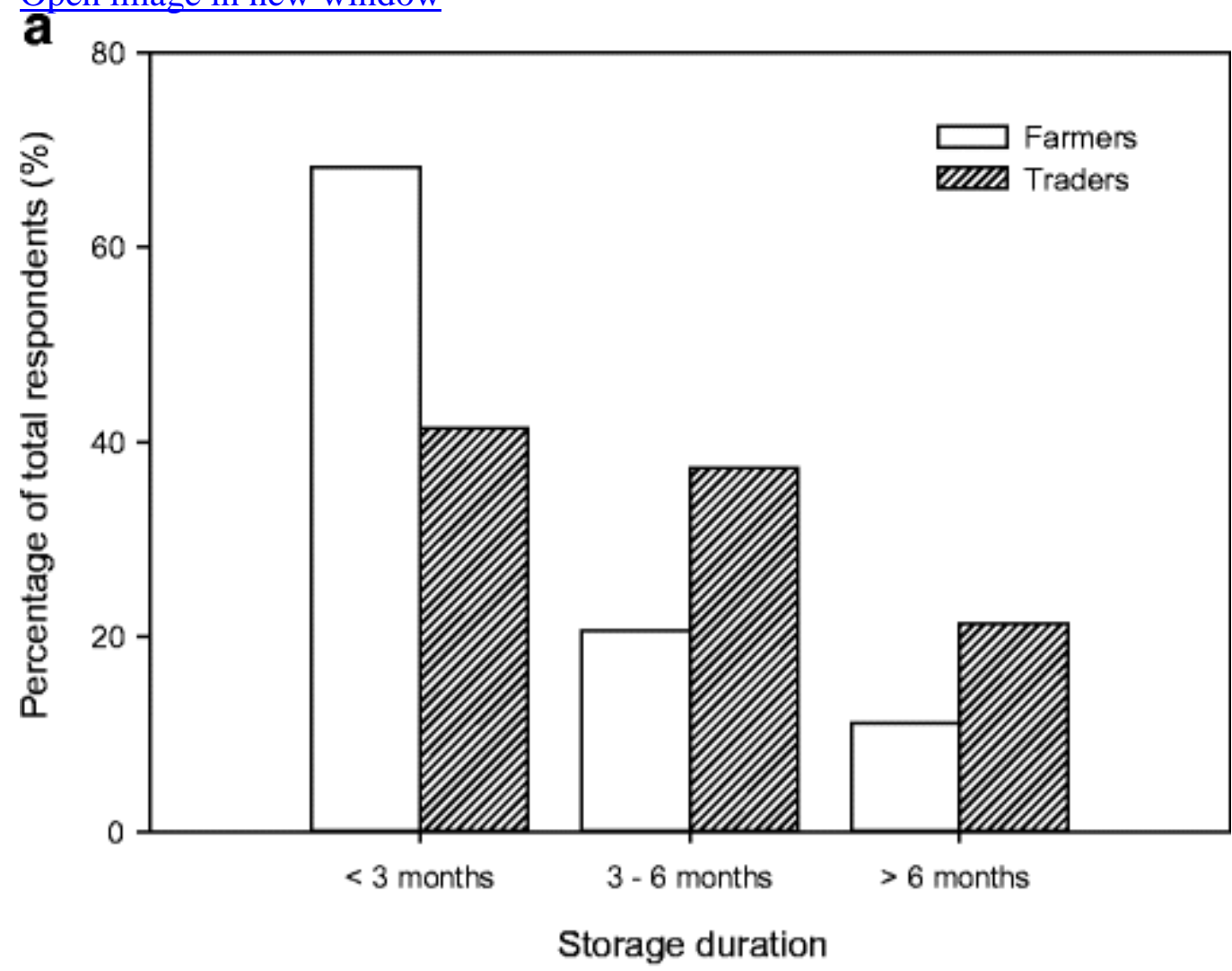

b

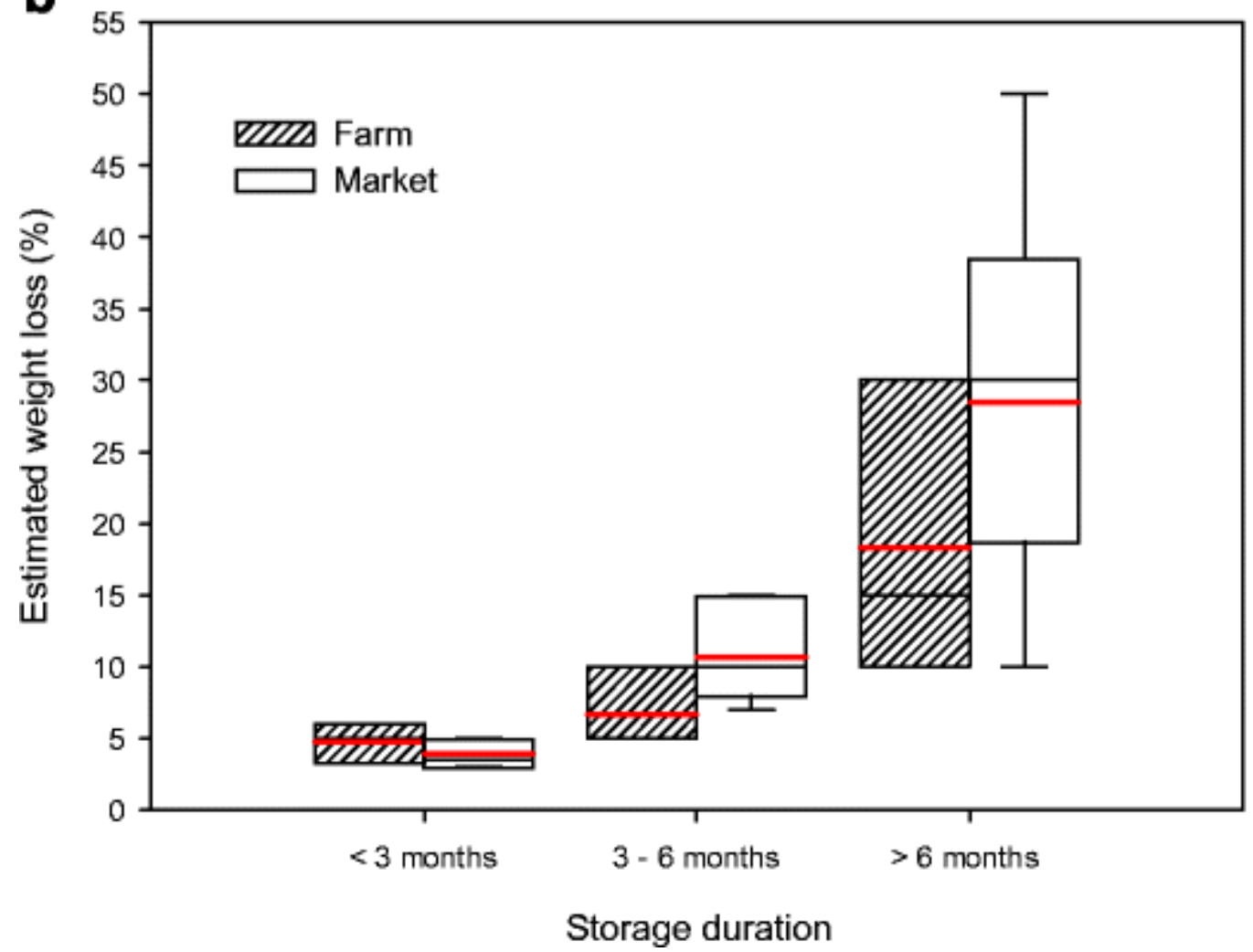

Fig. 7

Frequency of storage durations among farmers and traders after the production or procurement of the cassava chips (a) and a box-plot of mean percentage weight loss of dry 
cassava as reported by processor farmers (farm) and trader (market) during storage (b). Note: The red and black line in the box-plot represent the mean and median respectively. The top edge of the box is Q3 (third quartile) and bottom edge is the Q1. The whiskers represent the extreme value for each series. The boxes where there are no whiskers displays that the maximum and minimum values lies within Q1 and Q3

In Sodo, wholesalers and retailers reported that damage in both wet and dry seasons was similar and attributed this to insect infestation. However, in Bale and Gesuba the dry season was reported to have the higher infestation. The reason for this variation could be due to the lower altitude of Bale and Gesuba (1245 and 1499 m respectively), whereas Sodo is a highland area with an elevation of $2092 \mathrm{~m}$. Comparable magnitudes of losses during dry cassava storage have been reported from various tropical countries such as India, Ghana, Tanzania and Togo where these varied from 12 to $30 \%$ during three to six months storage (Wright et al. 1997; Stumpf 1998).

The single most important cause of weight loss recorded by previous investigations from SSA in dry cassava product was the wide range of insect species (Prostephanus truncatus, Sitophilus spp., and Ryzopertha dominica) feeding directly on cassava chips (Hodges et al. 1985; Wright et al. 1997). In a recent review of post-harvest losses in SSA, Affognon et al. (2015) reported these ranged from 20\% to 75\%, during 3-4 months storage and was primarily due to insects. Insect and mould damage to cassava chips cause considerable price discounts (up to 50\% (Affognon et al. 2015)) or total rejection by customers. As previously stated, household consumers, especially in the Wolayita zone (who were buying cassava for their consumption, excluding the food catering industry and commercial injera makers) preferred to buy chips rather than flour to assure the quality of the cassava (i.e. free from insect and mould damage).

The final milling step before cassava flour can be mixed with teff and maize was conducted exclusively with multi-purpose electric motor run stones or mortar mills. Flour mass recovery was $98.1 \%$. The literature on milling losses for cassava is limited; studies from Nigeria recommend hammers, pin mills and disc attrition mills (Emmanuel et al. 2010; Adesina and Bolaji 2013) for finer and higher flour recovery from dried cassava.

\subsection{Constraints and opportunities}

The cassava crop in Ethiopia is of strategic importance in order to combat food insecurity owing to drought. Ethiopian national research programs and international research institutes, such as IITA, are taking steps towards increasing cassava production and adapting new cultivars to the country's conditions. However, post-harvest VC development of the crop, especially towards improving the final product quality and reduction of food losses has been overlooked. Although the perspective of cassava expansion in the country is optimistic, the production and post-production systems in Ethiopia face some challenges. A SWOT matrix demonstrating the strengths, weaknesses, and opportunities for the cassava crop in Ethiopia is presented in Table 4. Particular stages in the cassava VC in the study area are discussed in the following sub-sections.

Table 4

SWOT matrix of Ethiopian cassava production and post-production system 
Swot

Strengths

1. Favorable climatic and edaphic conditions for adaption and adoption of high yielding cultivars.

2. Suitable for typical low input agricultural systems of Ethiopia.

3. Cassava thrives in marginal soils and periods of neglect.

Internal

4. Suitable for intercropping and as a fencing crop.

5. Suitable for areas prone to erratic rainfalls.

6. Good drought tolerance

7. Most economical source of calories during periods of food shortage.

8. Ability to blend cassava flour with other staple produce

\section{Opportunities}

1. Cassava roots and leaves as livestock feed.

2. Introduction of High-Quality Cassava Flour (HQFC) technique.

3. Promotion of cassava and other

External cereal composite flours in the bakery industry.

4. Introduction of yellow cassava (Vitamin A rich).

5. Industrial application (starch and starch based products, bio-ethanol).

\section{Negative}

Weaknesses

1. Late bulking (24-36 months).

2. Fragmented production by smallholders and informal marketing channels.

3. Weak market price mechanism

(fluctuations in market price).

4. Low product quality.

5. Lack of mechanization (particularly, manual peeling, chopping and, open air sun-drying).

6. Poor storage infrastructure (for the fresh and dehydrated product).

7. Poor insect pest management at farm and market.

8. Lack of awareness and poor promotion of various cassava based products.

9. Lack of crop national data base/ statistics.

10. Lack of cassava based food safety standards.

Threats

1. The low market.

2. Storage and vector insect pests (notably, whiteflies and Larger Grain Borer (LGB)).

3. Fear of cassava toxicity disorders among consumers.

4. Threat from East African strains of cassava mosaic virus (EACMMV, EACMV-UG) expansion in the region.

5. Yield losses and soil degradation as a result of the low-input farming system.

6. Weak market demand as disposable incomes rise in the country (perception as poor man's food). 
6. Development of centralized cassava processing units at woreda level.

7. Co-operative based marketing and development.

8. Better use of cassava peel.

9. Rural employment and income generation in cassava based products.

\subsubsection{Production and harvesting}

Long bulking times (24-36 months after planting) for the two predominant cassava cultivars (Kelle and Qulle) and labor requirement for manual harvesting of cassava root are two major concern for farmers during production and harvesting. The recommended optimum maturity for these cultivars was about 18 months. However, farmers tend to delay harvest in order to obtain higher yields. Lack of fertilizers and irrigation also play a role in slower accumulation of starch in the storage roots, which motivates farmers to extend crop duration. Keeping roots in-ground for long may also result in lignification and an increase in the incidents of biotic stress (rodent, pest and microbial) (Uchechukwu-Agua et al. 2015). For example, as mentioned before, scale insect infestation was present in close to $10 \%$ farms, for which the only possible control measures are phyto-sanitation and the introduction of naturally occurring predators such as Cybocephalus spp. (Lozano et al. 1981; Shonga et al. 2012). Adoption and adaptation of early bulking and bio-fortified ( $\beta$-carotenoids, iron and zinc rich) varieties can help farmers reduce delays in harvest and improve the overall nutrition obtainable from cassava, respectively (Howeler et al. 2013; HarvestPlus 2016; Parmar et al. $\underline{2017 \mathrm{~b}}$ ). Regarding harvesting methods, manual or pull-tool assisted cassava root harvesting are universally the most prevalent methods, however, in some Asian and Latin American countries tractor mounted mechanical harvesters have been used on large commercial plantations (Parmar et al. 2017b). In Ethiopian conditions a pull-tool (also sometimes referred as an up-rooter) can be introduced.

Better use of cassava by-products in the study area is required. For example, cassava leaves and peels have potential as animal feed. In the current literature, cassava leaves are sometimes referred to as 'tropical alfalfa' and are compared to soybean meal due to their high protein content (Morgan and Choct 2016; Parmar et al. 2017b), indicating their importance as animal feed, usually in the form of dry meal or silage.

\subsubsection{Processing, packaging, and transportation}

The inherent perishability of fresh cassava roots due to post-harvest physiological disorder (PPD) is a major problem for cassava producers and processors around the globe (Bokanga 2000; Oguntade 2013; Uchechukwu-Agua et al. 2015; Parmar et al. 2017b). The only practical solution which is currently available to the smallholders in the study area was to harvest a part of the total production which can be processed within a day (Nduwumuremyi et al. 2016). When most of the cassava is produced for sale rather than home consumption PPD creates a serious bottleneck for processor farmers and collectors due to the high manual labor 
requirements in a short period, which diminishes the producers' profit margins. The constraint (availability and cost) was mainly associated with manual peeling and chopping (slicing) and long open-air sun-drying periods. Lack of drying surface (plastic and polythene sheets) was a common concern of the processor farmers, some being forced to dry their cassava on brushed grass covers.

The intervention focus should be on implementing low-cost peeling, chopping and drying technologies to reduce labor hours, and drying times to improve the quality of the end product (cassava flour) and to reduce food losses. Some improved solar drying technologies suitable for cassava, based on mix-mode and natural convection, were discussed by Vijayavenkataraman et al. (2012) in a review on solar drying of agricultural produce. The basic low-cost equipment for peeling and chopping has been developed in other major cassava producing countries (especially in West Africa) with similar socioeconomic backgrounds (Bokanga 2000; Emmanuel et al. 2010; Howeler et al. 2013). For example, equipment such as handheld modified cassava peelers and mechanised grater/choppers used in Nigeria and Ghana can be directly introduced into the southern Ethiopian cassava producing areas. It is anticipated that introduction of such equipment would reduce losses, minimise the cost of labor and improve the quality of the final product. Naziri et al. (2014) related the higher mechanisation in South East Asia to lower post-harvest losses in comparison to SSA. Since the majority of cassava is used in the form of a flour composite with other cereals in Ethiopia, the introduction of HQCF (High-quality cassava flour) production technology based on pressing cassava mash before drying could significantly improve the quality of the product and reduce drying times. HQFC is a fine flour that is not fermented and is odourless, making it ideal for application in Ethiopia.

Industrial application of cassava in Ethiopia is in its infancy. Apart from a minor use for starch and adhesive production, potential uses such as livestock feed, starch derivatives (glucose, sucrose), the beverage industry and bio-ethanol production are non-existent. Ethiopia provides immense potential for cassava to be transformed from a famine reserve and rural staple to an industrial crop.

\subsubsection{Marketing and storage}

Insect infestation during storage of dried cassava chips was the leading cause of losses ( $30 \%$ of the total mass for storage longer than 6 months) at farm and market stages of the VC. These results are similar to those of other cassava producing countries (Hodges et al. 1985; Affognon et al. 2015; Hell et al. 2014). Insect management by traders and processor farmers need improvement. The contact insecticide, Malathion, may leave considerable residues in cassava flour (Uygun et al. 2005; Hell et al. 2014) and the fumigant (Aluminum phosphide) needs to be accompanied by airtight storage systems or packaging. Hermetic packaging is an economical option (commonly known as PICS (Purdue Improved Crop Storage) bags). However, they are only able to reduce losses if the product is free from any insects at packaging because the expulsion of air from cassava chips may not be as effective as that from grains and cereals, owing to air being trapped between the chips) (Hell et al. 2014). Development of other non-chemical options such as economical insect-proof packaging, use of pheromone traps, and general store hygiene, would not only reduce the storage losses of cassava chips but could be applied to other grains and cereals with similar problems. Experience from other SSA countries shows that the chances of adoption of a novel or improved technology are higher when its introduction is conducted in a participatory and 
inclusive manner (Nduwumuremyi et al. 2016). Thus, the interventions at various stages to improve cassava VC efficiencies have to be based on multi-stakeholder collaborations.

\section{Conclusion}

Although cassava is relatively new in Ethiopia, the crop plays an important role as a staple in the diets of people living in the southern region. Its importance is even higher during the lean season when other staples become relatively expensive for the poor. The predominant use of cassava in the study area was in the form of a composite flour with teff and maize to prepare staple flatbread, commonly known as injera. Storage of dried cassava chips was identified as the primary food loss 'hot spot' (on average 12-14\% loss of mass). The most important insect pest responsible for these losses were G. cornutus, H. brunneus, $R$. dominica, and $S$. zeamais. Open air sun-drying due to its long duration and dependency on dry weather conditions was responsible for food losses of up to $4 \%$ of the freshly peeled root mass. Other cassava VC stages, where minor (1-2\%) food losses occurred, were peeling and milling operations. This study calls for a number of interventions, which are required to reduce food losses and improve the quality of the product at various stages of the cassava VC in the study area. Training of the processor farmers in better use of the by-products generated during cassava production and processing could bring additional benefits. Moreover, the focus of the current study was limited to the southern region of the country. Extension of future studies to other cassava production areas (southwestern and Gambella regions) could provide further insights and comparisons within the country.

\section{Notes}

\section{Acknowledgements}

The authors thank German Academic Exchange Services (DAAD) and the project RELOAD (Grant No. 031A247A-D) for funding this study. This work would not have been possible without the support of the local partner organisations especially the Ethiopian Institute of Agriculture Research (EIAR) and Hawassa University, Hawassa.

\section{Compliance with ethical standards}

\section{Conflict of interest}

The authors declared that they have no conflict of interest.

\section{References}

1. Abuye, C., Kelbessa, U., \& Wolde-Gebriel, S. (1998). Health effects of cassava consumption in south Ethiopia. East African Medical Journal, 75(3), 166170.PubMedGoogle Scholar

2. Adesina, B. S., \& Bolaji, O. T. (2013). Effect of milling machines and sieve sizes on cooked cassava flour quality. Nigerian Food Journal, 31(1), 115119. https://doi.org/10.1016/S0189-7241(15)30065-5.CrossRefGoogle Scholar 
3. Adugna, A. (2014). Sountern Nations, Nationalities and people region: Demography and Health, (July), 1-20. http://www.ethiodemographyandhealth.org/AynalemAdugna_SNNPR_2017.pdf.

4. Affognon, H., Mutungi, C., Sanginga, P., \& Borgemeister, C. (2015). Unpacking postharvest losses in sub-Saharan Africa: A meta-analysis. World Development, 66, 49-68. https://doi.org/10.1016/j.worlddev.2014.08.002.CrossRefGoogle Scholar

5. Anshebo, T., Tofu, A., Tsegaye, E., Tadesse, T., Kifle, A., \& Dange, Y. (2004). New cassava varieties for tropical semi-arid climate of Ethiopia. In N. M. Mahungu \& V. M. Manyong (Eds.), Proceedings: 9th International Society For Tropical Root CropsAfrica Branch (ISTRC-AB) Symposium, Nairobi, Kenya, 526-531.Google Scholar

6. APHIS (2015). Larger Grain Borer 2004-2015. African Post-harvest loss Information System. http://www.aphlis.net/?form=larger_grain_borer. Accessed 12 Sept 2016.

7. Atser, G. (2012). Cassava varieties developed by IITA show promise of tackling famine in the horn of Africa. International Institute of Tropical Agriculture. http://liferay.iita.org/web/iita/2012-press-releases//asset_publisher/CxA7/content/cassava-varieties-developed-by-iita-show-promise-oftackling-famine-in-the-horn-of-africa\#.WZqmFlVJaUk. Accessed 17 Aug 2017.

8. Balta, A., Tessema, A., \& H/Wold, D. (2015). Assessment of household food security and coping strategies in Wolaita Zone : The case of Sodo Zuria Woreda. Journal of Poverty, Investment and Development, 18, 23-40. Google Scholar

9. Bekele, J., \& Butako, B. (2011). Occurrence and financial loss assessment of cystic echinococcosis (hydatidosis) in cattle slaughtered at Wolayita Sodo municipal abattoir, Southern Ethiopia. Tropical Animal Health and Production, 43(1), 221228. https://doi.org/10.1007/s11250-010-9680-5.CrossRefPubMedGoogle Scholar

10. Bellotti, A., \& van Schoonhoven, A. (1978). Mite and insect pests of cassava. Annual Review of Entomology, 23, 39-

67. https://doi.org/10.1146/annurev.en.23.010178.000351.CrossRefPubMedGoogle Scholar

11. Bokanga, M. (2000). Cassava: Post-harvest operations. In D. Mejia \& B. Lewis (Eds.), Information network on post-harvest compendium. Rome: FAO.Google $\underline{\text { Scholar }}$

12. CABI (2015). Prostephanus truncatus (larger grain borer). Invasive Species Compendium. http://www.cabi.org/isc/. Accessed 12 Sept 2016.

13. Chijindu, E. N., Boateng, B. A., Ayertey, J. N., Cudjoe, A. R., \& Okonkwo, N. J. (2008). The effect of processing method of cassava chips on the development of Prostephanus Truncatus (horn) (Coleoptera: Bostrichidae). African Journal of Agricultural Research, 3(8), 537-541.Google Scholar

14. Cock, J. (1985). Cassava: New potential for a neglected crop (p. 191). Epping: Westview Press, Bowker Publishing Co. Google Scholar

15. CSA (2007). Population and housing census of Ethiopia. Addis Ababa.Google Scholar

16. Desse, G., \& Taye, M. (2001). Microbial load and microflora of cassava (Manihot Esculenta Crantz) and effect of cassava juice on some foodborne pathogens. Journal of Food Technology in Africa, 6(1), 21-24. https://doi.org/10.4314/jfta.v6i1.19279

17. EARO (2000). Industrial crop research strategy. Addis Ababa.Google Scholar

18. Emmanuel, O., Olapeju, O., Dohou, S., Moutairou, E., Nankagninou, D., Komlaga, G. A., \& Loueke, G. (2010). Training manual (draft) processing of cassava into gari and high-quality cassava flour in West Africa (pp. 1-31). USAID, Songhai. http://www.coraf.org/database/publication/publication/cassavatrainingmanual.pdf. 
19. Enidiok, S. E., Attah, L. E., \& Otuechere, C. A. (2008). Evaluation of moisture, total cyanide and fiber contents of garri produced from cassava (Manihot Utilissima) varieties obtained from Awassa in southern Ethiopia. Pakistan Journal of Nutrition, 7(5), 625-629. https://doi.org/10.3923/pjn.2008.625.629.CrossRefGoogle Scholar

20. FAOSTAT. (2016). Production and area of cultivation for sweetpotato. Crops, National Production. Rome: Food and Agriculture Organization Statistics.Google $\underline{\text { Scholar }}$

21. FLWP (2016). Food loss and waste accounting and reporting standard. Washington, DC. ISBN: 978-1-56973-892-4. http://flwprotocol.org/.

22. GFSI (2014). Global food security index Ethiopia. The Economist Intelligence Unit Limited. http://foodsecurityindex.eiu.com/Country/Details\#Ethiopia.

23. Golob, P., Farrell, G., \& Orchard, J. (2002). Crop post-harvest: Science and technology, volume 1. UK: Blackwell Publication Company.CrossRefGoogle Scholar

24. Grace, M. (1977). Cassava Processing. Rome: Food and Agriculture Organization Of The United Nations.Google Scholar

25. Gustavsson, J., Cederberg, C., Sonesson, U., van Otterdijk, R., \& Meybeck, A. (2011). Global food losses and food waste: Extent, causes and prevention. International congress: Save food! https://doi.org/10.1098/rstb.2010.0126.

26. Grootaert, P., Pollet, M., Dekoninck, W., \& van Achterberg, C. (2010). Sampling insects: general techniques, strategies and remarks. In Manual on field recording techniques and protocols for all taxa biodiversity inventories, Abc Taxa, Belgium, 377-399. Google Scholar

27. Hagstrum, D., Klejdysz, T., Subramanyam, B., \& Nawrot, J. (2013). Atlas of storedProduct insects and mites. St. Paul: AACC International, Inc.Google Scholar

28. Haile, A. (2015). Cassava plantation, consumption and post-harvest processing in Ethiopia. Cassava Cyanide Diseases \& Neurolathyrism Network (CCDN), 26, 79. Google Scholar

29. Haile, A. (2014). Evaluation of cassava cultivars and methods for roots processing in development of cassava composite flours for production a household staple Injera in Ethiopia. Ethiopia: Addis Ababa University.Google Scholar

30. Haile, A., Retta, N., Abuye, C., Science, F., Ababa, A., \& Ababa, A. (2014).

Evaluation of methods for roots processing on removal of anti-nutritional factors of selected cultivars of cassava (Manihot esculenta C.) grown in Ethiopia. Journal of Science \& Development, 2(2), 87-100. Google Scholar

31. Harvestplus (2016). Biofortified staple food crops: Who is growing what? file:///C:/Users/Aditya/Downloads/HarvestPlus_BiofortifiedCropMap_2016.pdf. Accessed 15 Nov 2016. Google Scholar

32. Hell, K., Edoh Ognakossan, K., \& Lamboni, Y. (2014). PICS hermetic storage bags ineffective in controlling infestations of Prostephanus Truncatus and Dinoderus spp. in traditional cassava chips. Journal of Stored Products Research, 58, 5358. https://doi.org/10.1016/j.jspr.2014.03.003.CrossRefGoogle Scholar

33. Hodges, R. J., Meik, J., \& Denton, H. (1985). Infestation of dried cassava (Manihot Esculenta Crantz) by Prostephanus Truncatus (Horn) (Coleoptera: Bostrichidae). Journal of Stored Products Research, 21(2), 73-77. https://doi.org/10.1016/0022474X(85)90024-4.CrossRefGoogle Scholar

34. Hodges, R. J., Buzby, J. C., \& Bennett, B. (2011). Postharvest losses and waste in developed and less developed countries: Opportunities to improve resource use. Journal of Agricultural Science, 149, 3745. https://doi.org/10.1017/S0021859610000936.CrossRefGoogle Scholar 
35. Howeler, R., Lutaladio, N., \& Thomson, G. (2013). Save and grow: Cassava. A guide for sustainable production and intensification. Rome: Food and Agriculture Organization Of The United Nations.Google Scholar

36. Isah, M., Ayertey, J., Ukeh, D., \& Umoetok, S. (2012). Damage and weight loss of dried chips of cassava, cocoyam, yam and plantain exposed to Prostephanus Truncatus (horn)(Coleoptera:Bostrichidae) over three different time durations. Journal of Entomology, 9(3), 137-145.CrossRefGoogle Scholar

37. Kassa, Z. (2013). Ethiopia: Cassava becoming source of food in Ethiopia. Addis Ababa: Ethiopian Radio and Television Agency http://allafrica.com/stories/201306031862.html. Accessed 17 Aug 2017.Google $\underline{\text { Scholar }}$

38. Kebede, A., Teshome, B., Wondimu, A., Belay, A., Wodajo, B., \& Lakew, A. (2012). Detoxification and consumption of cassava based foods in south West Ethiopia. Pakistan Journal of Nutrition, 11(2), 237-242.CrossRefGoogle Scholar

39. Kummu, M., de Moel, H., Porkka, M., Siebert, S., Varis, O., \& Ward, P. J. (2012). Lost food, wasted resources: Global food supply chain losses and their impacts on freshwater, cropland, and fertiliser use. Science of the Total Environment, 438, 477489. https://doi.org/10.1016/j.scitotenv.2012.08.092.

40. Laekemariam, F. (2016). Soil nutrient status of smallholder cassava farms in southern Ethiopia. Journal of Biology, Agriculture and Healthcare, 6(19), 1218. https://doi.org/10.1080/00103629809370135.Google Scholar

41. Lebot, V. (2009). Tropical root and tuber crops: Cassava, sweet potato, yams and aroids. Crop production science in horticulture no. 17, CABI Publishing, Oxfordshire. doi: https://doi.org/10.1017/S0014479709007832.

42. Legesse, Z. L. (2013). Impact of cassava production in ensuring food security of farm households: The case of Amaro Woreda in southern nations, nationalities and peoples regional state of Ethiopia. Haramaya University. Retrieved from http://213.55.85.90/bitstream/handle/123456789/797/Zeme1.pdf?sequence=1\&isAllo wed $=$ y.

43. Legesse, Z. L., \& Geta, E. (2015). Impact of cassava production in ensuring food security of farm households: The case of southern Ethiopia. World Applied Sciences Journal, 33(11), 17461759. https://doi.org/10.5829/idosi.wasj.2015.33.11.15621.Google Scholar

44. Lozano, J.C., Bellotti, A.C., Reyes, J.A., Howeler, R., Leihner, D., \& Doll, J. (1981). Field problems in cassava (2 ed., p. 192). Cali: Centro Internacional de Agricultura Tropical (CIAT seres no. 07EC-1).Google Scholar

45. Markos, D., Hidoto, L., \& Negash, F. (2016). Achievements of cassava agronomy research in southern Ethiopia in the last two decades. Agriculture and Food Sciences Research, 3(1), 1218. https://doi.org/10.20448/journal.512/2016.3.1/512.1.12.18. CrossRefGoogle $\underline{\text { Scholar }}$

46. Morgan, N. K., \& Choct, M. (2016). Cassava: Nutrient composition and nutritive value in poultry diets. Animal Nutrition, 2(4), 253261. https://doi.org/10.1016/j.aninu.2016.08.010.CrossRefGoogle Scholar

47. Mulualem, T. (2012). Cassava (Mannihot esculenta Cranz) varieties and harvesting stages influenced yield and yield related components. Journal of Natural Sciences Research, 2(10), 122-129.Google Scholar

48. Mulualem, T., \& Dagne, Y. (2015). Farmer's appraisal, manifestation and scaling up of improved cassava technologies in moisture stressed areas of the southern Ethiopia. 
Journal of Genetic and Environmental Resources Conservation, 3(1), 100105.Google Scholar

49. Mulualem, T., Weldemichael, G., Benti, T., \& Walle, T. (2012). Genetic diversity of cassava (Manihot Esculenta Crantz) genotypes in Ethiopia. Greener Journal of Agricultural Sciences, 3(9), 636-642.Google Scholar

50. Mulualem, T., \& Weldemicheal, G. (2013). Evaluation of the adaptability and acceptability of improved cassava (Manihot Esculenta Crantz) varieties in southwest. Greener Journal of Agricultural Sciences, 3(8), 658-562.CrossRefGoogle Scholar

51. Naziri, D., Quaye, W., Siwoku, B., Wanlapatit, S., Phu, T. V., \& Bennett, B. (2014). The diversity of postharvest losses in cassava value chains in selected developing countries. Journal of Agriculture and Rural Development in the Tropics and Subtropics, 115(2), 111-123. Google Scholar

52. Nduwumuremyi, A., Melis, R., Shanahan, P., \& Asiimwe, T. (2016). Participatory appraisal of preferred traits, production constraints and postharvest challenges for cassava farmers in Rwanda. Food Security, 8(2), 375388. https://doi.org/10.1007/s12571-016-0556-z.CrossRefGoogle Scholar

53. Nebiyu, A. (2004). Genetic diversity of cassava in Ethiopia: Its implication for food security and the need for biotechnology research. In A. A. C. Alves (Ed.), Sixth International Scientific Meeting of the Cassava Biotechnology Network (p. 39). Cali: Centro Internacional de Agricultura Tropical (CIAT).Google Scholar

54. Nebiyu, A. (2006). Genetic variations in cassava at Jimma, Southwest Ethiopia. Tropical Science, 46(3), 171-175. https://doi.org/10.1002/ts.171.CrossRefGoogle $\underline{\text { Scholar }}$

55. Nebiyu, A., \& Getachew, E. (2011). Soaking and drying of cassava roots reduced cyanogenic potential of three cassava varieties at Jimma, Southwest Ethiopia. African Journal of Biotechnology, 10(62), 1346513469. https://doi.org/10.5897/AJB10.2636. Google Scholar

56. NMSA. (1996). Climate and agronomic resource of Ethiopia. Addis Ababa: Meteorological Research Report Series.Google Scholar

57. Oguntade, A. E. (2013). Food losses in cassava and maize value chains in Nigeria: Analysis and recommendations for reduction strategies. Eschborn: Deutsche Gesellschaft für Internationale Zusammenarbeit (GIZ) GmbH. Google Scholar

58. Parmar, A., Kirchner, S. M., Langguth, H., Do, T. F., \& Hensel, O. (2017a). Boxwood borer Heterobostrychus Brunneus (Coleoptera: Bostrichidae) infesting dried cassava: A current record from southern Ethiopia. Journal of Insect Science, 17(1), 18. https://doi.org/10.1093/cercor/bhw393. CrossRefGoogle Scholar

59. Parmar, A., Sturm, B., \& Hensel, O. (2017b). Crops that feed the world: Production and improvement of cassava for food, feed, and industrial uses. Food Security. https://doi.org/10.1007/s12571-017-0717-8.

60. Ravindran, V. (1993). Cassava leaves as animal feed: Potential and limitations. Journal of the Science of Food and Agriculture, 61(2), 141150. https://doi.org/10.1002/jsfa.2740610202.CrossRefGoogle Scholar

61. Shonga, E., Addis, T., Mesele, G., \& Tadesse, T. (2012). Cassava scale: A new threat for a food security crop in Ethiopia. The African Journal of Plant Science and Biotechnology, 6(1), 80-83.Google Scholar

62. Stumpf, E. (1998). Post-harvest loss due to pests in dried cassava chips and comparative methods for its assessment: A case study on small-scale farm households in Ghana. Humbolt University, Berlin. Retrieved from http://www.fao.org/wairdocs/x5426e/x5426e04.htm. 
63. Tadesse, T., Degu, G., Shonga, E., Mekonen, S., Addis, T., \& Yakob, B. (2013). Current status, potentials and challenges of cassava production, processing, marketing and utilization: Evidence from southern Ethiopia. Greener Journal of Agricultural Sciences, 3(4), 262-270.CrossRefGoogle Scholar

64. Taye, M., \& Biratu, E. (1999). Effect of storage and cooking practices on the total cyanide content of two cassava (Manihot Esculenta Crantz) cultivars. Ethiopian Journal of Science, 22(1), 55-66.Google Scholar

65. Uchechukwu-Agua, A. D., Caleb, O. J., \& Opara, U. L. (2015). Postharvest handling and storage of fresh cassava root and products: A review. Food and Bioprocess Technology, 8(4), 729-748. https://doi.org/10.1007/s11947-015-1478z.CrossRefGoogle Scholar

66. UN (2017). World Population Prospects of United Nations. https://esa.un.org/unpd/wpp/DataQuery/. Accessed 14 Jan 2018.

67. USAID (2016). Ethiopia: Food security outlook. Addis Ababa.Google Scholar

68. USDA (2016). National Nutrient Database for Standard Reference Release, 28 https://ndb.nal.usda.gov/ndb/foods/show/2907?manu=\&fgcd=\&ds $=$. Accessed $14 \mathrm{Jan}$ 2018.

69. Uygun, U., Koksel, H., \& Atli, A. (2005). Residue levels of malathion and its metabolites and fenitrothion in post-harvest treated wheat during storage, milling, and baking. Food Chemistry, 92.Google Scholar

70. Vijayavenkataraman, S., Iniyan, S., \& Goic, R. (2012). A review of solar drying technologies. Renewable and Sustainable Energy Reviews, 16(5), 26522670. https://doi.org/10.1016/i.rser.2012.01.007.CrossRefGoogle Scholar

71. Webb, P., von Braun, J., \& Yohannes, Y. (1992). Famine in Ethiopia: Policy implications of coping failure at national and household levels. Washington, DC: International Food Policy Research Institute.Google Scholar

72. Westerberg, A., Zhang, J., \& Sun, C. (2012). Cassava: A multi-purpose crop for the future. In C. Pace (Ed.), Cassava: Farming, uses and economic impact (pp. 145-159). New York: Nova Science Publishers, Inc..Google Scholar

73. Wobeto, C., Corrêa, A. D., De Abreu, C. M. P., Santos, C. D. D., \& Pereira, H. V. (2007). Antinutrients in the cassava (Manihot Esculenta Crantz) leaf powder at three ages of the plant. Ciência e Tecnologia de Alimentos, 27(1), 108-

112. https://doi.org/10.1590/S0101-20612007000100019.CrossRefGoogle Scholar

74. Wright, M., Jeremiah, S., Wareing, P., Rwiza, E., \& Msabaha, R. (1997). Post-harvest storage problems in dried cassava and sweet potato in Tanzania. Kent, UK. Google $\underline{\text { Scholar }}$

75. Xue, Z., Zhang, J., Zhang, Y. L., Li, C. B., \& Chen, S. (2015). Test and analysis on the mechanical properties of cassava stalks. The Journal of Animal \& Plant Sciences, 25(3), 59-67.Google Scholar

76. Yebo, B., \& Dange, Y. (2015). Agronomic research achievements and findings of taro and cassava crops in Ethiopia: A review. Journal of Agronomy, 14(1), 15.CrossRefGoogle Scholar

77. Zhu, W., Lestander, T., Örberg, H., Wei, M., Hedman, B., Ren, J., et al. (2015). Cassava stems: A new resource to increase food and fuel production. GCB Bioenergy, 7(1), 72-83. https://doi.org/10.1111/gcbb.1211. CrossRefGoogle Scholar 